\title{
Letter from A.V. Chayanov to V.M. Molotov on the current state of agriculture in the USSR compared with its pre-war state and the situation in agriculture of capitalist countries (October 6,1927$)^{2}$
}

\author{
A.V.Chayanov
}

Alexander Chayanov wrote this analytical note to Vyacheslav Molotov in early October 1927 to discuss plans for the agricultural development of the first five-year plan in the USSR. Chayanov begins with a brief review of the history of world agriculture in the early twentieth century. He identifies two poles in this evolution: western (American typically North America and partly South America, South Africa, and Australia) and eastern (Indian-Chinese, typically agrarian overpopulated countries). The American type of agricultural development is based on farms that use machinery and wage labor and are controlled by the vertical system of financial capitalism. The Indian-Chinese type of agricultural development is characterized by agrarian overpopulation of the peasantry under dominant pre-capitalist relations, exceptional labor intensity, and widespread bondage rent and credit. The rest of the world's regions can be placed between these two poles. In the late nineteenth and early twentieth centuries, Russia is a paradoxical, complex mixture of these two types.

Chayanov believed that in the agrarian science of pre-revolutionary and prewar Russia, these polarized agrarian worlds were reflected in the agrarian-economic disputes of the so-called "southerners" and "northerners" about the strategy of agricultural development. "Southerners" insisted on turning Russia into a "hundredpercent America” by the forced development of farmers' agriculture. The "northerners" suggested supporting the regional strata of the middle peasantry and its own vertical cooperation to prevent the seizure of the village by trade and financial capital. Chayanov considered himself a "northerner". He argued that the post-war, post-revolutionary village has changed significantly. First, the younger generation of peasants who had experienced the world war and Russian Revolution set the tone. Second, the Soviet agronomic science and cooperation of the 1920 s contributed to the real progress of peasant farms. Soviet Russia has a unique chance to find a fundamentally new path of rural development, thus avoiding the Scylla of Americanfarmers' dependence on financial capital and the Charybdis of the Indian-Chinese stagnation of peasant overpopulation. Instead of American vertical agrarian integration through the dominance of financial capital over farmers, Soviet vertical integration

1. V.M. Molotov (1890-1986) - a famous Soviet party leader, one of the closest associates of I.V. Stalin, a member of the Politburo of the Central Committee of the Communist Party of the Soviet Union (CPSU) from 1926 to 1957, the prime minister of the Soviet government from 1930 to 1941.

2. As the Head of the Commission of the Central Committee of the CPSU, while preparing theses about the work in the countryside for the XV Congress of the CPSU, V.M. Molotov asked A.V. Chayanov to write his ideas and suggestions on the development of agriculture in the USSR. This text is A.V Chayanov's answer to the request of V.M. Molotov. 
was to promote the development of diverse forms of peasant cooperation with the support of the socialist state. In the final part of the note, Chayanov considers the ratio of industry and agriculture in the first five-year plan and predicts a radical socialtechnological change under agricultural industrialization.

The Soviet leadership ignored the ideas of this note: Stalin rejected Chayanov's democratic type of vertical cooperation of the peasantry and preferred a horizontal type of cooperation in the form of collectivization.

The publication with comments was prepared by A.M. Nikulin.

Key words: agrarian policy, peasants, farmers, agricultural cooperation, agrarian capitalism, socialist agriculture, ways of agricultural development

DOI: 10.22394/2500-1809-2018-3-3-6-18

In response to your questions posed to me by G.N. Kaminsky, ${ }^{3}$ I send this brief note.

Unfortunately, I had only a few hours to write it, which prevented me from concretizing my ideas and providing specific illustrations for them. Moreover, a certain abstractness of the note is also determined by the fact that, for about a year and a half, I have been completely isolated from practical economic work. Therefore I can assess the situation in the village based only on the data of our academic expeditions.

Nevertheless, if you need it, I can develop any of my ideas with all the necessary detail and provide them with sufficient factual basis. I apologize for somewhat careless editing of the note due to very little time.

Comradely greetings,

Professor A.V. Chayanov

\section{Basic types of world economies before the war ${ }^{4}$}

To most clearly reveal the distinctive features of the present stage of the Soviet agriculture, we must consider it in terms of evolutionary development and compare it with the development of farming in capitalist countries, starting from the pre-war period. When considering the state of world agriculture before the war, we can identify its two polar types.

1. American agriculture is based primarily on the labor of the farmer who personally works physically on his farm together with two or three wage workers. His economy is medium in size, extensive, highly mechanized, and firmly engaged in the capitalist system of the national economy in the form of so-called vertical concentration. Various banks of land credit, elevator, land-reclamation, and trade compa-

3. G.N. Kaminsky (1895-1938) - a prominent figure in the Bolshevik Party, Head of the trade union of agricultural and forestry workers, Deputy Head of the Board of the Union of Agricultural Cooperation of the USSR.

4. The headlines underlined in the typescript are given here in bold italics.

Letter from

A.V. Chayanov to V.M. Molotov 
8 nies tightly control this economy and extract a significant capitalist profit from it. Cheap land, expensive labor, extensive low-labor-inтЕория tensive farming with large capital investments and wide mechanization are foundations of this type of economy.

There are exact opposites of such American forms in the eastern countries - China, India, and some others. In these countries, excessive agrarian overpopulation with a persistent, feudal, social order determines the development of family forms of economy, exceptional labor intensity of farming, and widespread enslaving relations in the fields of rent, credit, and employment. Expensive land, cheap labor, hyper-intensive and very labor-intensive farming, lack of both cars and horses, and feudal relations instead of capitalist ones are the national, economic basis of the Chinese forms of agriculture.

Paradoxically, the pre-war Russian agriculture seems to be a zonal mixture of these two types, or rather a mixture of trends of these two types.

On the eve of the war, the Russian village was at the brutal turn that accompanies the transition from the feudal system to the commodity one. Only a few decades ago, the village managed to get out of true feudalism and had not yet got rid of many of its elements.

For example, the main difference in the agricultural economy of our country from America is that, almost from its very first years, the settlement of America took place under a commodity economy. This determined differences in population density over the territory according to different zones of intensity entirely dependent on market conditions. As for the settlement of our country, for the centuries under the natural, feudal system, regardless of market zones, the majority of the population settled and was concentrated in fertile areas with more or less safe, strategic positions. Such a model of population distribution basically took shape in the seventeenth century and persisted until the beginning of the rapid development of the commodity economy at the end of the nineteenth century.

The development of commodity relations presented quite different requirements for the distribution of population by creating new, commodity-concentration zones around the Black Sea and Baltic Sea ports. As a result, "historically predetermined" distribution became glaringly inconsistent with the one required by the market conditions. There were obvious regions of agrarian overpopulation as well as under-populated agrarian areas. The contradictions between them could not be mitigated by recent migration flows.

In our agrarian over-populated regions, such an historical process spawned a Chinese-like land regime - family forms of farming, cheap labor, inflated land prices, flourishing slave relations, and pre-capitalist forms of peasant farm differentiation.

In the northern industrial regions, the agrarian crisis was mitigated and at the same time aggravated by seasonal, labor migration and extensive development of local handicraft industries. These ham- 
pered the formation of a real class of industrial proletariat and deprived the village of everything above the average level. In contrast, in the extensive, under-populated areas of the south, southeast, and east, there was a rapid evolution towards American forms of economy. These included the rapid elimination of pre-capitalist forms of family economy, growth of farmer-type elements with machinery, and the active replacement of pre-capitalist and enslaving forms of differentiation with developing forms of truly capitalist differentiation.

Even from the national economy perspective, the economic structure of these regions resembled capitalist America. The high marketability, investment of significant loan capital, and the development of vertical concentration in both capitalist and cooperative forms mimicked the initial stages of all elements that constitute the American organization of agriculture. We have none of these elements in agrarian overpopulated areas, which persistently maintain the pre-capitalist forms of the natural family regime with slowly developing marketability and cooperation.

Before the war, there were two main trends in both the peasantry and agronomic circles. First was to strive for a "pure America" and to develop farmers' elements in our agriculture in every possible way (the Kharkov group, Sokalsky, Matseevich, etc.). ${ }^{5}$ Second was to rely on middle peasants and try to develop cooperative forms of vertical concentration of the economy. This would allow the rationalization and organization of the peasant economy to possibly avoid the seizure of the village by commodity and financial capital and keep control over sales and financing routes in the hands of cooperatively organized masses (Moscow agronomy at the Congress in 1911).

The war caught both trends in their first steps and in the literary forms of the struggle. Such was the situation on the eve of the October Revolution. What changes has the Soviet period of our history brought, and what were the simultaneous changes in the countries of capitalist agriculture?

\section{Contemporary trends in American agriculture}

Let us start with foreign countries. In the American-type countries, the rapid development of credit and intermediary cooperation led to the almost complete ouster of private, commercial capital; it fell under the strongest influence and control of financial capital. The cooperatively organized farmer established closed relations with a bank to enter a system of a capitalistically organized economy. That farmer is the hero of the day in farming for both Americas, Australia, and South Africa.

5. Agrarian economists from the south of Russia, especially those who published the Agronomic Journal in Kharkov (K.A. Matseevich, S.A. Sokalsky), are the main representatives of agronomist southerners who primarily support the liberal, capitalist farmers' development of rural Russia.

RUSSIAN PEASANT STUDIES $2018 \cdot$ VOLUME $3 \cdot$ NO 3 
The very complicated ideology of this movement can be seen in the attached translation of an article by the Argentine professor,

теория Arano (Buenos Aires). ${ }^{6}$ America added a significant set of technical improvements to this system of the organization of agriculture: new sorts of bread led by the super-manitoba; the melilot exported from the USSR, which promises a significant revolution in the forage crops issue; milk yields of bovine record holders exceeded 1,000 poods, ${ }^{7}$ etc. In contrast, the organizational economic relations in the agrarian, overpopulated countries, except for Japan, remained almost the same as before the war.

\section{The current state of agriculture in the USSR}

Let us now consider the current situation in our agriculture after ten years of Soviet power. To study this issue carefully, we must quite sharply divide the problem into two parts.

\section{Changes in the production mechanism of agriculture}

First, what changes have occurred in the very production mechanism of agriculture, and, second, what changes have taken place in the structure of agriculture as a whole and as an organized part of the entire national economy of the USSR?

Let us first focus on the first issue. Certainly, one of the major factors determining today's structure of agriculture in the USSR is the agrarian revolution of 1918 to 1920 , which eliminated the remnants of the already dying landlord economy. Obviously, specific results of this upheaval differed by region. If the landlord economy was still viable and significant, the agrarian revolution completely transformed the peasant economy. For instance, in 1926, our institute of agricultural economy repeated a research that A. Shingarev ${ }^{8}$ had once conducted in two villages in the Voronezh province. He called them in 1906 hopelessly "endangered" due to the severe land shortage. In 1920, despite the devastation of civil war and the tragedy of famine, both villages became "resurgent" due to a significant increase in the size of land plots. For the most part, the revolution allowed peasants to keep the money for all rent payments up to 20 million desiatinas, which they had previously paid to landowners. I consider as even more impor-

6. This article by Professor Arano was not found in the archive.

7. Pood is an old, Russian measure of weight. One pood is equal to $6.38 \mathrm{~kg}$; 1000 poods are equal to 16.38 tons.

8. A.I. Shingarev (1869-1918) - a liberal public figure, doctor, publicist, author of the book "Endangered Village: A Sanitary-Economic Study of Two Villages of the Voronezh Uyezd' (Saint Petersburg, 1907). 
tant the black redistributions in the resurrected land community and dekulakization, which destroyed the farmers' elements of the village.

As a result, our agriculture lost high-commodity enterprises, which inevitably affected the commodity mass of agricultural products and export opportunities. Undoubtedly, they can be restored and even surpassed only by a significant increase in marketability by the mass economy. The liquidation of the landlord economy was so complete that, unfortunately, the state managed to keep very small unscattered agricultural lands. Thus, we must admit that out state farms and collective farms did not inherit any mass production capability. The old slogan of 1918 and1919 - "From peasant economy through communes to state farms" 9 - has clearly lost its meaning and relevance. The lands of our state farms were seriously scattered during the liquidation period from 1921 to 1923 . They are hardly enough even for the auxiliary agricultural activities (experimental fields, breeding farms, state farms, seed plots, etc.) that are necessary for supporting the peasant economy as soon as its massive rise begins. The socialist sector of our agriculture should obviously develop in some other ways.

After the destruction of large forms of the landlord economy and a considerable part of the farmers' economy that had already formed before the war, the production mechanism of our agriculture consisted, to a greater extent than before, of the still persistent pre-capitalist, family-type economy. It also included aggravated, bonded relationships in the rent of agricultural implements and working cattle due to impoverishment. This is clearly shown by the budget-study expeditions of the Institute of Agricultural Economy into the flax and sunflower regions (see corresponding tables in the attached book). ${ }^{10}$

However, since 1921, under the pressure of the developing commodity economy, this set of leveled farms has shown processes of the rebirth of pre-capitalist differentiation and capitalist differentiation of the farmers' type. This is especially true for areas that were accumulating farmers' elements already before the war. For example, according to the Central Statistical Administration of the USSR, in August 1926, there were 11.8 annual, term, and monthly wage workers per 100 households in the North Caucasus, 9.0 in Dnepropetrovsk, and 22.7 in Crimea, whereas in the agrarian, overpopulated, black-soil areas, there were 3.2 , and on the right bank of Ukraine, 6.2. We have no doubt that if there had been no revolution, in these regions the process of americanization would have more deeply captured peasant masses. Even now it could have been more significant if it were not restrained by the measures of our social policy.

There was a simultaneous and much deeper second process in the pre-war agriculture - the development of agricultural cooperation. We will discuss it later.

9. The words are underlined in the text.

10. The book was not found in the archive. 
Thus, after the revolution, formally, in the private-property perspective, the production mechanism of agriculture preserved its preтЕория war, peasant basis as well as two development tendencies towards farmers' economy and the cooperative concentration of the middle peasant farms. This is naturally reflected in the current, corresponding, ideological approaches. However, although the very type of the production mechanism of the economy remains the same, we can identify a number of profound changes in it.

We do not attach much importance to the fears of destroying the means of production of the peasant economy, especially considering draft cattle and implements. Although such fears undoubtedly exist, they do not seem threatening.

First, the huge percentage of non-sowing and horseless peasants must be significantly reduced, because it undermines commercial, peasant activities and seasonal work in the city, i.e., peasant farms are not horseless; they simply do not need implements. Second, before the war and due to the parceling of farms - not only in agrarian overpopulated areas but also in the north in general - horses and implements were such a heavy burden and were so little used that their reduction did not mean a decline in the production capacity of agriculture in general. It led only to the development of the rent of these means of production, i.e., it had social rather than production consequences. There is an absolute and persistent lack of horses and implements only in the eastern, agrarian, overpopulated areas.

In general, due to the low capital intensity of our pre-war economy, some destruction of the means of production did not have catastrophic consequences. Its capital can be easily restored, as can be seen in the example of a number of regions that were crushed by the famine of 1921 .

The positive changes are much more significant. First, we should note the almost ubiquitous and quite complete change of managerial personnel in the peasant economy. Some of the old men who were in control fifteen years ago before the war withdrew from business and others were "overthrown". Today in the peasant economy, more than half the "power" is in the hands of the former soldiers of the world war and civil war. They were disciplined in the schools of the revolution and front and have an immeasurably wider outlook than the owners of peasant farms in the period from 1906 to 1915. This new "staff" of peasant farms is head and shoulders above the former one, more mobile, and open to agro-improvements. Perhaps, this new peasant is more aware of his petty-bourgeois interests, but, undoubtedly, he has already escaped the grip of his grandfather's traditions.

Second, we can already provide this new "economic entity" with new farming techniques. Our experimental stations and local agronomy, which took their first heroic steps before the war, today already have certain knowledge. In many respects, conclusions about the ten-year research have already been made, and we have considerable results in 
the rationalization of the economy. The attached diagram-cartogram, made by the Institute of Agricultural Economy on the proposal of the National Commissariat of Agriculture, is based on the data from experimental fields and agro-assistance. It presents a regional picture of our technical proposal for the peasants who are looking for new ways to reorganize their farms (see the large table attached). ${ }^{11}$

This combination of the new peasant with the new achievements of agronomy has already provided many examples of reaching our agronomic goals. Shunga and Ugreshi ${ }^{12}$ are known for their 2,000 poods $s^{13}$ of potato harvest per desiatina; the fodder-grass cultivation is just as known and is spreading rapidly in the Moscow province and a number of other regions. Kurovo ${ }^{14}$ and other villages are less known al-though their field-crop cultivation is not inferior to the experimental fields of the Timiryazev Agricultural Academy. It is virtually unknown that a few months ago at the Volokolamsk exhibition and competition of cows, the cows with milk yields of 200 buckets $^{15}$ per year did not win any awards, because the prize winners' milk yields were much higher. And there are hundreds of such examples. Thus, the peasant economy has moved off dead center and is developing its own resources.

Undoubtedly, this development would have been much more massive if the incentives to expand the economy were not extremely weakened in our village. One can confidently say that the incentives for expansion are one of the main minima of our economy, especially for production.

It is not so much about price policy but rather about the extraordinary progress of taxation that is sometimes prohibitive in relation to the expansion of the economy. An economically expanded peasant enterprise can pay the highest tax rate but, psychologically for the farm owner, such proceeds do not justify the strenuous efforts necessary to expand the economy.

This is the state of the very production mechanism of agriculture.

\section{Changes in the social-economic organization of agriculture in the USSR}

One can say that all the changes listed above contain no socialist elements at all and bring nothing new in social life as compared with the pre-war situation. There are the same petty-bourgeois elements in addition to the obvious trends towards the transformation of the

11. There is no attachment in the archive.

12. Villages of the Kostroma province of Russia.

13. 2000 poods are equal to 32.7 tons.

14. A village in the Tula province of Russia.

15 . 200 buckets are equal to 2460 liters.

RUSSIAN PEASANT STUDIES 2018 . VOLUME $3 \cdot$ No 3 
14 pre-capitalist forms of the family economy [into] capitalist farms in a number of regions. However, this should not confuse us. At the curтЕория rent stage in the transformation of agriculture, the problem is not in the destruction of the peasant economy as such but in completely different forms of the growth of socialist elements. These will not only bring to naught the growth of farmers' elements but will also lead inevitably to the radical social reorganization of the structure of agriculture. At the current stage of agricultural development, these elements should be sought in the vertical concentration of agriculture. Here, and mainly here, the current decisive accumulation of socialist elements takes place.

Just as a crowd of armed people does not make an army, agriculture is not simply the sum of peasant farms. Agriculture, like the army, gets its identity and becomes an active agent when it receives an organization and a sum of known social ties that control individual farms and are drivers of their economic activities.

These social ties have almost no material expression, and this is the only reason for the observers of today's village to maintain that by appearance, it is a completely unchanged village of autocratic Russia. Actually, it is the system of these ties, which are in many respects absolutely different from the pre-war ties, that completely changes the internal essence of our agriculture. At the current stage of development, it is in these ties that one should look for differences from the past. I emphasize the current stage, because at the next stage these differences will extend to the production mechanism itself.

In the newest forms in the development of American agriculture, we saw that capitalism seized it with the financial support of the cooperative system of organized farmers and by introducing all kinds of capitalist auxiliary enterprises into the very heart of the farmers' economy (processing, elevators, refrigerators, etc.). In fact, we are going through the same process in the USSR. The only difference is that instead of financial capital, we have the organizing force and capital of the socialist state under construction.

This is the quantitative expression of the growth of the socialist elements in our economy by 1927: 66,839 primary agricultural cooperatives uniting $7,369,000$ peasant farms, 16,962 dairy, potato-grater, handicraft and other cooperative enterprises; hundreds of millions of loans through the cooperative channel of the Central Agr[icultural] Bank; about 500 breeding farms and state farms; 9,800 rental stores, seed-cleaning and coupling stations; and 7,000 poods of the seed fund (for improved seed material). If we add here a near monopoly position and, for some products, quite a monopoly position of state procurers in the market of agricultural raw materials and in foreign trade, then, despite the fact that our agriculture is a spontaneous set of 20 million smallest farms, the question is basically not how to establish state control over this set but what should be the direction and objectives of such control. 
Under the further growth of these elements and forms of communication, the issue of the growth of farmers' elements in the village will certainly not lose its social significance but will almost completely lose its organization-production importance. This is because, under the inevitable drawing of the farmers' economy into the system of control described above, farmers' elements in production will eventually accept the role of technical agents of the state regulation of the economic system.

Moreover, in some extensive areas (the left bank of the Volga river and Akhtuba) and in the regions of special cultures (Crimea, etc.), the farmers'-type farms can be the only mechanism capable of coping with the production tasks in those areas, which cannot be solved by one- or two-horse farms of the middle peasant. They are almost incapable of organizing production cooperative associations in today's village. If such farmers'-type farms are included in the system of controlled agriculture, they are absolutely safe provided there are restrictions on territorial distribution and a spontaneous increase in the elements of the public economy.

The foregoing with sufficient clarity answers the question about the difference between the old village, the new village, and the village of capitalist countries of the American type. Today's village preserved the old, family-organized, production mechanism in its peasant part and has received a new system of social-economic ties that allow the gradual accumulation of cooperative and other elements of the public economy in the very heart of peasant farms. This new system of social ties is growing stronger every year and organically enters the system of the planned state economy, thus, turning agriculture itself into an element of the national economy of the USSR under socialist reconstruction. In the countries of the American-type agriculture, there are also changes in the system of social ties, but this system in its cooperative part is linked with the bank financial capital and, thus, subordinates all agriculture to the control of capitalist centers. In our opinion, this is the essential difference in the current historical processes.

\section{Challenges for the evolution of agriculture in the USSR}

Today our Soviet agriculture faces two, main, acute problems posed by life itself. 1) The danger of a farmers' transformation of the peasant economy. First, given all the socialist-type ties described above, will the pre-capitalist family forms of the peasant economy rapidly turn into the farmers' type of economy, thus, changing the social basis of our whole system of control and support of agricultural production? Undoubtedly, there is a danger of this kind of transformation, and many contemporary figures who prefer to follow the line of least resistance would consider this transformation among the most desira- 
16 ble ways of developing our agriculture. However, we consider such a direction of evolution and assistance to it, if it is rather a rule than тЕория an exclusion, as a movement along the line of least resistance on the verge of liquidation.

We are convinced of the complete possibility of developing a quantitative accumulation of the socialist elements of agriculture in our farming in the form of a much more essential support than the current purely intermediary form. We believe that cooperation and elements of the public economy can follow the links and stages of the development of capitalism in the manufacturing industry. The gradual development of the public economy elements must go along the line: credit - purchase - sales - enterprises auxiliary for agriculture - organization of primary processing - joint organizations of draft and joint cultivation of land, and socialization of a number of branches of agriculture into large cooperative enterprises. This is the only form of accumulation of socialist elements in our village that can resist the development of the farmers' economy trends.

The simultaneous development of electrification, all kinds of engineering facilities, a system of warehouses and public premises, and a network of improved roads and cooperative loans lead to such a fast quantitative growth of the elements of the public economy that the whole system qualitatively transforms from a system of peasant farms into a system of public, cooperative economy of the village. This economy is based on public capital and leaves the technical implementation of certain processes for the private farms of its members practically in the form of a technical assignment.

Certainly, in such a system of organization of agriculture, there is no place for the farmers' economy. The system itself can hardly be called a petty-bourgeois type, for it undergoes such deep processes of transformation that it must be considered a form of consistent, socialist, public economy. This system can further develop and replace the remaining individual plots with larger enterprises of the collective-farm type organized as agricultural, production mechanisms of the optimal size.

All the above is somewhat abstract. However, when visiting Shungu, Kurovo, and a number of our other regions, we saw firsthand the trends of this kind, albeit underdeveloped.

2) The place of agriculture in a system of the industrialization of the national economy of the USSR. Another issue of the same urgency as the issue of overcoming the farmers' forms of economy is the place of agriculture in the industrialization process that is currently carried out in the national economy of the USSR.

If we consider the industrialization of the national economy of the USSR as the most important among the immediate tasks of economic policy, we should specify the concept "industrialization" in more detail. It would be incorrect to define industrialization as exclusively the development of the manufacturing industry and power plants, 
because industry cannot develop without simultaneous changes in those branches of agriculture that are connected with it. Therefore, we should always speak and think of industrialization as the restructuring of the entire, national economy to make it more industrial. The growth of the share of industry in the national economy should imply the largest changes in the agricultural basis of industry. Specifically, when developing industry, we must completely modify the structure of its raw materials base and, in every possible way, promote commodity forms of agriculture as a market for other products of future industry.

Undoubtedly, we must start industrialization of the country with industry, and, in the first years of work, the greatest material resources should be invested in industry. Certainly, for some time, the rapidly developing manufacturing industry and transport and power plants can be supported by the old agricultural basis. But it is equally certain that in a few years, there will be an inevitable and predictable gap between the already restructured industry, on the one hand, and the corresponding agricultural base - on the other. Then, and I believe that this "then" can come within the next five years, we will have to use most of the efforts and means to organize such an agricultural sector of the industrialized economy that will ensure sustainable existence and development of all its industrial elements.

Therefore, already in the coming years in the most important costs in manufacturing, transport, and energy sectors, we must systematically foresee the above-mentioned turning point and plan in advance all the activities that we will eventually have to implement.

These are my main thoughts of your questions in a few hours at my disposal and without the possibility to refer to any research and samples from the actual material, due to lack of time.

Razumovskoe

A. Chayanov

Izvestia of the Central Committee of the CPSU. 1989. No. 6 . Pp. 210-219 ${ }^{16}$.

Пер. на англ. И.В. Трочук

16. The document from the Archive of the President of the Russian Federation as a part of the V.M. Molotov's fund was transferred to the Russian State Archive of Social-Political History. 


\section{8 Письмо А.В. Чаянова В.М. Молотову о представлении}

записки о современном состоянии сельского хозяйства СССР по сравнению с его довоенным положением

\section{и положением сельского хозяйства капиталистических стран от 6 октября 1927 r.}

\section{А.В.Чаянов}

Аналитическая записка Александра Васильевича Чаянова Вячеславу Михайловичу Молотову написана в начале октября 1927 года для обсуждения планов сельскохозяйственного развития на первую пятилетку в СССР. Записка Чаянова начинается с краткого обзора истории мирового сельского хозяйства в начале XX века. Чаянов выделяет два полюса этой эволюции: западный (американский, характерный для Северной Америки, отчасти для Южной Америки, Южной Африки и Австралии) и восточный (индийско-китайский, характерный для аграрно-перенаселенных стран). В центре американского типа сельского развития находятся фермерские хозяйства, применяющие машины и наемный труд, контролируемые вертикальной системой концентрации финансового капитализма. Индийско-китайский полюс сельского развития характеризуется аграрным перенаселением крестьянства и господством докапиталистических отношений, исключительной трудоемкостью, повсеместным распространением кабальной аренды и кредита. Остальные регионы мира находятся между этими полюсами, и Россия в конце XIX - начале XX века являет собой парадоксально сложную смесь двух полярных типов.

Чаянов отмечает, что в аграрной науке дореволюционной и довоенной России эти поляризующиеся аграрные миры нашли отражение в спорах аграрников-экономистов "Южан" и "северян" о стратегии сельского развития. "Южане» предлагали взять курс на "стопроцентную Америку" с форсированным развитием фермерства, "северяне" - сделать ставку на региональные слои среднего крестьянства и его собственную вертикальную кооперацию, предотвратив захват деревни торговым и финансовым капиталом. Себя Чаянов относил к "северянам". По его мнению, послевоенная, послереволюционная деревня сильно изменилась: во-первых, тон теперь задает молодое поколение крестьян, прошедшее через события мировой войны и российской революции. Во-вторых, советская агрономическая наука и кооперация 1920-х годов способствуют реальному прогрессу крестьянских хозяйств, и у советской России появился уникальный шанс найти принципиально новый путь сельского развития, избегая Сциллы американско-фермерской зависимости от финансового капитала и Харибды индийско-китайской стагнации крестьянского перенаселения. Вместо американской вертикальной аграрной интеграции через господство финансового капитала над фермерами советская вертикальная интеграция должна представлять собой развитие разнообразных форм крестьянской кооперации при поддержке социалистического государства. В заключительной части записки Чаянов освещает вопросы соотношения промышленности и сельского хозяйства в планах первой пятилетки, предсказывая социальный и технический перелом под влиянием сельскохозяйственной индустриализации. Идеи чаяновской записки были проигнорированы советским руководством: Сталин отверг чаяновский демократический тип вертикальной кооперации крестьянства, предпочтя горизонтальную кооперацию коллективизации.

Публикация подготовлена, примечания составлены А.М. Никулиным.

Ключевые слова: аграрная политика, крестьяне, фермеры, сельскохозяйственная кооперация, аграрный капитализм, социалистическое сельское хозяйство, пути сельского развития. 